\title{
The Analytic Challenges of Studying the Middle East and its Evolving Media Environment
}

\author{
Annabelle Sreberny \\ School of Oriental and African Studies, University of London \\ Email: as98@soas.ac.uk
}

\section{Keywords}

Middle East; Media; Political Economy; Political Communication; Cultural Studies

Over a decade ago, I wrote an essay entitled 'Media and Democratization in the Middle East: The Strange Case of Television' which contextualized the then rapid development of new media channels in the region and assessed their potential for the development of political awareness and participation, especially among women. The piece was republished a number of times (Sreberny 1998; 2000). Now I am delighted to write for the first issue of a new journal that is devoted to the analysis of contemporary mediated culture in the region. An important new area of intellectual research and analysis is opening up that poses real challenges to extant analytic frames and disciplinary approaches. I base the following on some arguments in the original article which still have validity today.

One of the challenges that the fields of Media and Cultural Studies face is their changing objects of study. In essence, we are concerned with contemporary history and our 'objects' are part of the here and now while always in some kind of flux. Media organizations, genres and contemporary cultural practices frequently change. The media consolidate and break up as economic entities. The media develop new formats and program ideas. The media reflect and construct representations of a range of other 'objects' that include inter-media commentary about other media channels. The media engage with and define the 'political' in a variety of ways. These are dynamic entities. They are buffeted by economic, political and cultural logics and they are significant players within them. Indeed, even this description could be challenged as 'old-media'- centric. With convergence of forms, functions and technologies, with broadcasting and narrowcasting over the internet and with mobile telephony as conduits of 
personal and public messages, the 'object' of Media Studies is becoming even broader and less amenable to analysis through the now 'classic' paradigms.

Such changes pose a serious challenge to the 'subject' of Media and Cultural Studies. How do we study these phenomena? What are the appropriate terms of reference, of theory? So too does the changing geography, both in terms of the different spatialities summoned by different forms of communication but also at the point of origin of message production. Media Studies, like all the social sciences, is embedded in the historical experiences of Western industrial capitalism, liberal democracy and bounded nation-states. Even the sub-field of International Communications, perhaps the dominant approach of the late twentieth century, essentially looked out with a scoping gaze from the West toward the rest of the world and proferred a set of assumptions about media dynamics in political, economic and cultural contexts that were for the most part totally 'foreign' to the authors. The favoured paradigm of 'cultural imperialism' suggested an active 'West' (usually singular) and a receiving - if not fully receptive - 'non-West' (equally and bizarrely singular). There was little recognition of pre-existing forms of cross-cultural contact, most particularly through processes of imperialism and colonialism, that had already profoundly marked much of the non-West and imprinted its own traces in the West (Sreberny-Mohammadi 1997). There was little recognition of the processes of incorporation of new technological forms of communication including print, and their impact and use by local actors (for example, on the significance of newspapers in the Constitutional Revolution in Iran, see Dabashi 2007). Occasionally, there has been an encounter with postcolonial theory, but often this has been stretched so thin as to give little analytic purchase on which to build. There has been all too little sense made of any internal dynamics of growth, change and development within non-Western societies. The West was all too often set up as the animator of non-Western puppet societies.

A new thrust, toward 'de-westernizing' media studies (Curran and Park 2000), and toward 'internationalizing media studies' (special issue of Global Media and Communication, 3, 3, December 2007), has been promulgated. But so far this has proferred studies of media in non-Western countries - useful but insufficient - or hurried classifications by levels of democratization and regulation - as conceptually limited in political terms as older paradigms were in media terms. Sometimes, too, the mundane rationales for such 'internationalizing' of the field have been occluded. These include the difficulties of publishing about non-Western locales. Certain members of the academic community are beginning to tire of rejection slips from publishers that pompously declared a piece to be interesting but too focused on one particular country. On the flip side, pressure from international students to study 'their' countries can become tedious when there is no available material. 
Rather more powerfully, one effect of the rise of 'globalization' theorizing has been to challenge the 'methodological nationalism' (Beck 2002) that pervaded and still pervades - social theory. A rich set of neologisms has developed to deal with more complex encounters that includes 'international', 'trans-national', 'trans-cultural', and 'global'. While these terms as yet lack clear definition and a settled common usage, they do indicate significant conceptual ferment and ask important questions about the imagined 'spaces' of social and cultural practice that should be our analytic focus. A second consequence, especially in Media and Cultural Studies, is a new focus on regionality, on clusters of countries felt to share certain common features or to be caught up in real world alignments and organizational practices. It appears that the more the globalization, the greater the need to study its impacts in a specific place and time. The wider the diffusion of media channels and content, the greater the growth of national and regional foci. The field has seen the rise - through formal organizations, conferences, books and journals - of (at minimum) Chinese, Indian, Iranian, pan-European, Scandinavian, intra-Asian, Latin American and African Media and Cultural Studies. We have recognized and claimed the right, enfin, to focus on the specificities of place in dialogue with the generalities and theoretical constructs of the 'discipline'; indeed, with the hope of developing the field through engagement with various kinds of 'difference' from its earlier US/UK-centric 'objects' of study. Grounded studies, offering thick description, conducted by people learned in the langauges, histories and cultural mind-sets of the place of study, may begin to pose a new set of questions and challenge the inarticulate assumptions of media theory through engagement with 'other' places. New 'objects' of study might indeed challenge and develop the 'subject'.

Of course, one danger lurking here is that regionality simply becomes a larger framework of analysis with little analytic bite and that the constituent practices and historical discourses that work to produce 'regionality' are ignored. The language of continental landmasses originates with the Greeks, with the 'new worlds' recognized in the 15 th century. But does geography really produce commonality? What endures and what changes in global realignments? What might be the purpose of a new journal focused on the Middle East?

\section{What, Where and When is the Middle East?}

Perhaps a stringent definition of the 'Middle East' is not necessary; perhaps that is an emergent project or, perhaps, it is merely a linguistic convenience to demarcate a starting point of analysis. The 'Near East' was a term used by archaeologists, geographers and historians to include Anatolia (the 'Asian' part of modern 
Turkey), the Levant (Israel, Jordan, Syria and Lebanon), Georgia, Armenia, and Mesopotamia (Iraq and eastern Syria). The term 'Middle East' is preferred by contemporary political and economic analysts, but does not have very clearly defined geographical borders. The 'Middle East' is a demarcation by colonial fiat, through lines in the sand, albeit that the linguistic trope is now widely used within the region itself. It is often glossed as MENA, Middle East and North Africa, to include the Maghreb, linked to the Middle Eastern heartland through Arabic. What is clear is that it is a European construct, in English, of a remarkably complex, differentiated and fascinating area, whose only fixity is, after all, its geographic location (and then with blurring boundaries). The name would have a different valence if it were instead the 'Middle West'. To ask when is the Middle East is also to ask about who uses this designation and for what purposes?

The point about internal differentiation is easily made, although regularly forgotten, the lapse aided by political rhetorics and media discourses that wish to portray the region all too simply as politically volatile, violent and dominated by extremist Islam. The region reveals remarkable differentiation along almost any indicator one cares to chose. While Arabic is a dominant langauge across the region, it too enjoys many variants. Turkish, Persian and Hebrew are also important regional languages. Similarly, while Islam is the dominant religion, there are significant and varied communities of Jews, Greek Orthodox, Protestants, Druze, Copts, and confessionalism dominates the politics of some states, such as Lebanon. There is also intense differentiation within Islam, not only the increasingly repeated notion of the 'Sunni/Shi' ite division' which carries more rhetorical and political weight that the historical and empirical realities warrant, but also between Wahhabist conservatism, Ismaeli openess and Shi' ite radicalism as well as highly divergent interpretations of the appropriate role of religion in politics. Ahmed (2008) provides a brilliant critique of the reduction inherent in identiy politics, the diversity within Islam and also the possibility of a new 'ethic of belonging' for Jews in the region. Cultural 'diversity' might not operate with the same categories as within Western societies, but that does not mean there isn't any.

Economically, the region has countries with amongst the highest GNP in the world (UAE; Kuwait; Israel), mainly the result of oil rent, and the lowest (Yemen). Some countries have particularly high compositions of population with significant proportions of non-nationals. In Kuwait, for example, approximately $70 \%$ of the population in 1990 were non-nationals, with long and complex procedures for claiming citizenship; where citizenship remains an issue, participation and democratization are stalled. There is also considerable population mobility. In the 1980 s, Iran experienced the largest refugee population of any country in the world in the form of Afghani war refugees, 
while by 2008 the Iraq war had displaced perhaps 4 million refugees to Jordan and Syria and beyond. Palestinians remain a highly dispersed diaspora. In many countries, incoming guest-workers play an important economic role while also bringing different cultural practices with them. It is also a region that has exported people. Turkish 'guest-workers' now constitute three generations of German immigrants, while global Lebanese, Palestinian, Armenian and Iranian diasporas and significant numbers of Saudi and Algerian dissidents have transformed cities such as Sao Paulo, Los Angeles and London. A number of countries have a youthful population skew, Iran being repeatedly described as having $70 \%$ of its population under 30 years of age, and dissent across generations is palpable across the region.

What I would like to do in the next section is to take three dominant approaches in Media Studies - political communication; political economy and cultural studies - and explore, in an admittedly sketchy manner, their use and abuse in relation to studying the region. Subsequently, I'll make an argument for the utility of a three-fold spatial typology - nation, region, transnationality - as ways of framing different sets of issues.

\section{Politics, What Politics?}

Politically, the Middle East is a region that has flirted with periods of constitutional reform, sometimes inspired by Western practices, as in the Iranian Constitutional Revolution of 1905 and the period of Turkish modernization under Ataturk. It has also experienced two early and powerful communist parties, the Iranian Communist Party established already in 1920 (later, the Tudeh Party, 1941) and the Iraqi Communist Party in 1934. There have been strong republican movements (Iraq; Egypt); popular uprisings (Palestine; Yemen) and revolutions (Iran, 1979) (Sreberny-Mohammadi and Mohammadi 1994).

There have also been UK and US-supported coups (Iran, 1953) and considerable financial support to regimes friendly to the West. For example, in 2008, US foreign aid to Egypt, which is pegged at two-thirds of US foreign aid to Israel, averages $\$ 2.2$ billion per year. Sales of military equipment to the region are also in the billions of dollars and seem to be an acceptable alternative to democratization for US foreign policy. Certainly, the external pressures toward 'democratization' are unequally distributed, with many client states remaining remarkably immune.

The point here is that the region has a history of deep politicization, having witnessed many forms of political participation and considerable external intervention. The current period needs to be seen within such longer histories, both as an outcome and as a particular point of departure. 
One of the most powerful models of modernization, the paradigm of 'communications and development', emerged out of empirical research conducted in Turkey, Syria, Iraq and Iran in the late 1950s by Daniel Lerner, which resulted in his contentious volume The Passing of Traditional Society (1958). The model was deeply flawed (triumphalist, unilinear, stagist) including the suggestion that the region 'lacked' politics; then, as now, the meanings of politics and democracy were reduced to and limited by the formal rituals of voting in elections, blind to the actual politics evident on the street, in formal organizations and informal circles and in the dissident media and literary voices of the region. Lerner's work is a vivid example of the use of a framework derived from specific Western historical experiences (and probably, of limited reach even there) to a very different context, that occluded all the contravening evidence available to him. In another way, the model was also forty years premature in its assumptions about modernizing dynamics of which media were both index and catalyst, but which have really only manifest themselves in the region from 1991 and more powerfully in the noughties. Lerner's work prompted a 'rebuttal' in the form of an argument about the 'passing of modernity' (Mowlana and Wilson 1999) in the region, an argument that rode on the coat-tails of the Iranian revolution and the revitalization of Islamist politics in the region. This was and is a ludicrous argument, especially now in a period of intense incoporation into global markets, expansion of investment, institution-building and media growth. Non-oil-based economic development, that includes trade, financial services and construction, tourism and consumerism, is propelling many states into fascinating formations of modernity, where the political, economic and socio-cultural are very differently configured than in Western historical development. Not the 'passing' but the provocations of modernity are evident.

The region produced many women's movements at the start of the twentieth century (Egypt; Syria; Iran), has engendered some notable female political, literary and cultural figures (the mantra that Um Kulthum was a more powerful figure of national cohesion than Nasser is validated in its repetition) and its current media environment includes many women's print and broadcasting channels that interrogate the move from patriarchal to neo-patriarchal (Sharabi 1988) forms of power. Yet women are encountering difficulties in getting into positions of formal political and professional power (note the inability of Shirin Ebadi to perform her judicial duties in Iran, or the imprisonment and harassment of Nawal Al-Saadawi in Egypt) and gender politics - whether experienced within the private sphere or played out in public - remains a potent force for change in the region.

While a number of states are long-standing republics, many of those are highly centralized mobilizing regimes, and the area still boasts many of the last autocratic monarchies in the world. One of the enduring problems for 
many states in the region is how to build a modern state infrastructure and administrative capacity, establishing modern political and civic institutions; the difficulty of institution-building is perhaps one of the few arguments from Samuel Huntington that has any validity for the region. I'll say more about state formations in the next section.

My point here would be that there is much to be explored under the rubric of 'political communication', a useful subset in the discipline, but that the approaches and methods cannot simply be transposed from Western contexts. To ask only about formal processes, about elections and public opinion, is to miss a range of informal politics - from dowreh to coffee-houses to graffiti to blogging - developed within the rhythms and interstices of the region. Similarly, to ask only about Islam, now glossed into a far more limited 'Islamism', in the region without recognizing the region's varied secular politics and the range of voices within Islam is to take an ideological argument as the driver for academic investigation. What are the political issues around in the region? What are the peoples of the Middle East most concerned about? What are the debates in the cafes, on the street, in the maidan? Again, grounded analysis, informed by both history and contemporary evidence, is what is most needed.

\section{A Slippery Political Economy: Oil vs Islam}

While crude neo-Orientalist argument has focused on Islam as an impediment to democracy, by now a well-critiqued argument, far more significant structuring factors include foreign intervention in the region and oil. Many, but not all, of the states in the region owe their high GNP and economic development to oil extraction and are primarily 'rentier states' (Mahdavy 1970; Luciani 1994). Under this peculiar mode of production, the state does not need to engage its workforce - which is very small - and raise revenue; hence structurally there may be less pressure for democratization. Iraq and Iran are rather different formations than Saudi Arabia and the Gulf States, since the former did produce strong popular movements for change. From the outside, Western concerns about the oil resources of the region have led to persistent military and political intervention, with support for clientilist and un-democratic regimes against movements of self-determination, although Iraq and possibly still Iran were brought to heel for other reasons. It has even been suggested that there exists 'an historic incompatibility of oil and democracy' (MERIP 1992).

Again, the contemporary period manifests fascinating elements of both continuity and rupture. As oil prices flow over the ominous $\$ 100$ dollars per 
barrel mark, Western economies feel the strain; by May 2008, prices had reached over $\$ 120$. It is noteworthy that in the current (spring 2008) collapse of subprime markets in the USA and the teetering banking system (note Northern Rock and Bear Stearns), Arab finance capital is awaited as the savior of the day. Oil rent functions as a primitive form of accumulation and the silent shift from the Swiss to the Arabs as the world's bankers and financiers is as noteworthy as the much trumpeted rise of China and India as the world's new engines of capitalism (Strange 1997). That there are tensions between the needs of states and the needs of the capitalist system as a whole is evident, the dialectic between the territorial and capitalist logics of power that Harvey (2005) analyzes. Actually, the exceptionalism of oil-rent states can be stretched too far, since other Southern states, in Latin America for example, face similar dilemmas about state-lead development policies in the transition to capitalism.

Here again, this means not the abandonment of 'political economy' but the need for a much wider, more holistic application of its approach, away from a media-centric obsession to a contextualization of the media within a broader framework. Evidently a media channel (such as Al-Jazeera) that does not pay for itself, running up million dollar deficits, and has to be maintained through digging deep into an oil-rent pocket, suggests a very particular relationship between oil, governmentality and media. Normative approaches from Westcentric political economy that all too often become merely a concern about increasing conglomeratization or even privatization in the transnational media industries do not map easily onto the region. That there might be (might be!) positive roles for the state in media and cultural policy, and that the very weakness of the private sector may also affect cultural creativity (may!) are issues that need to be investigated, not blocked. Khiabany (2007: 487) has neatly argued,

Within media studies the continuing debate about the role of the state, especially around the fields of cultural policy, political communication, censorship, and democratic processes, is an indication of the significance of the role of the state for cultural and symbolic production. Terms such as 'public' and 'private', 'restricted' and 'free', 'state' and 'market' have formed some of the most controversial pairings of categories in modern liberal societies. Success, progress and freedom in this narrative have been measured according to the degree of separation between these parings and the increased 'undermining' of the role of the state. It is in this context that certain normative assumptions about the nature of communication in the global south have resurfaced which see the state as the main obstacle/problem in development of media and the main enemy of media freedom, and the market as the solution and the source of liberation.

The region offers a range of forms of governmentality, of political 'regimes' mainly at the authoritarian and non-participatory end of the spectrum. But it also reveals different modalities of political decision-making and of repression 
(that may invite perhaps a comparative analysis of secret police), media censorship and control of the internet. The region offers a laboratory of repressive systems but also shows moves toward more hegemonic formations, examples including the Islamic Republic of Iran as a mobilizing state and Turkey's attempt to integrate Islamic 'parties' into the political process.

Also, the manner in which states mask their direct involvement in media organizations with a 'front' of enterprise is interesting, while sometimes the state actively supports privatization and modernization. What room is there for the development of privately-owned cultural industries to build institutional capacity, to construct a salariat of creative people, to establish structures in which talent can grow and novel forms of cultural production can be imagined? Can a petit (not necessarily very petty) bourgeoisie be encouraged that invests in and supports small-scale media and cultural enterprise? How might this interface with state and larger commercial investment in ICT and telephonic infrastructures? The stronger bourgoisies of Egypt, Turkey and Iran do not solely rely on the state and often present fomidable challenges to state policy.

In post-conflict situations, with weak state institutions and powerful pressures toward fragmentation (Afghanistan and Iraq spring to mind), is there no rationale to be made for a centralized media system to invite populations into a national frame?

Similarly, an abstracted search for a public sphere in the Middle East might be the wrong forensic tool to use. What if a public sphere is weakly developed because of overweaning state power? What if the public sphere is also a maledominated social space? Will the development of media channels sufficient in themselves help construct or enlarge a national public sphere? How would we know if a public sphere exists or not - what are the criteria or index of it? Can we simply examine one form of communication, say the press or blogging, abstracted from the wider system and claim that it is successful or not, controlled or not?

Perhaps we need to hold a greater sense of paradox, contradiction and refusal to move to early closure in our analyses. The remarkably large Iranian blogosphere (Khiabany and Sreberny, forthcoming) is both an index of an emerging public sphere as well as a site of government repression, the locus of both public and 'private' political discourses, the space where both religious and secular voices are articulated. To argue for only one side of those pairings is to lose the rich and ambiguous whole and probably to come to too rapid conclusions about the nature and outcomes of these practices.

We cannot undertake a serious political economic analysis of the media without examining the peculiar political economies in the region. If an argument against mediacentrism has any value, it is even more significant in the Middle East. 


\section{Cultural Studies, Representation and Audiences}

A traveling 'cultural studies' often simply celebrates the post-modern bricolage of images and ideas that circulate in the contemporary global media environment as all being of equal value, worth and significance. But often the focus is still on 'Western' imagery circulating in a hostile Middle East, the most obvious expression of which is taken to be the response to the Danish cartoons. What happens when the Spice Girls and the Qur'an collide? what kind of and whose imaginary prevails? A more grounded cultural studies would explore the range of representations - of Islam, of women, of the West - the political discourses and cultural products that are produced from within and circulate about the region. Isn't there as much contention in Saudi Arabia about the presentation and visibility of a Lebanese woman newsreader as her equivalent on CNN? The dominant and false binary of the 'West' and the 'rest' occludes the wide range of representations of women, of femininity and sexuality available across the media in the region, and the competition between different state and state systems for Arab audiences.

The youthfulness of populations partly accounts for the popularity of, for example, Star Academy in Lebanon and elsewhere as well as the debates about reality TV that have cropped up in Bahrain and Saudi Arabia. The production of rai, rap and hip-hop is creating vibrant music scenes in Marrakesh, Damascus, Cairo and Istanbul; the diminution of Jewish communities in the region and Iraqi exilic moves to Israel invites the synthesis of Arab and Jewish musical traditions in late-night Tel Aviv, and African rhythms can be found in Morrocan gnawa. Contemporary visual arts and photography, calligraphy, poetry and novels, carpets and textiles, architecture and tilework, build on ancient craft and pattern, the old and the new engaged in on-going re-formations. Here the field must connect with other and older disciplines to avoid a naïve sense of discovering new topics that in fact have long and distinctive pedigrees of scholarship.

The historic importance of urban centers - Damascus claimed as the longest continually inhabited city in the world - is reinforced with the significance of entrepot development in Dubai and Sharjah, the rebuilding and revitalization of Beirut (before summer 2006) and Amman, and construction of airports and seven-star hotels to support the influx of professionals and tourists (Davies 2006). These spaces form new loci in the network of global cities (demanding an analysis that moves away from the out-moded Tokyo-London-New York axis) but also raise questions about aesthetic style, architectural motifs and cultural dynamism. Vision and engineering are not new phenomena in the region. Isfahan was planned, its architecture not only manifesting the power of religion but also the best of local craft and design, and built already in 1643 
to withstand earthquakes. It would be a tragedy if contemporary planning manifested only Westernized nouveau-riche taste and the worst trappings of consumerist modernity, so the analysis of urban development and the nature of internal debates about this are vital subjects for study.

Tensions between the pressures of conservatism, tradition, cultural maintenance and those directed toward change and modernization exist in every society: where are the tensions manifest, who are their protagonists, what are the likely short-term and long-term outcomes? The analysis of media systems in and of themselves is of limited significance. But examined as institutions within national and transnational processes of political liberalization and democratization, of social transformation and the emergence of gender equality, of economic globalization and pressures to fiscal modernization, the contradictory and ambivalent role of the media can become a significant analytic focus.

Each of these three classic paradigms can ask some useful questions, while each alone quite overdetermines the causal logic of impact it desires/predicts. Only an encounter between paradigms, a post-paradigmatic conversation, can pose new questions, even new methods for accessing the answers, an intermingling of voices from the outside and the inside, and can push our understanding further. While empirical work takes place within paradigmatic structures, when the latter become so rigidified that only normal science endlessly repeats itself, then is the (need for the) birth of a new paradigmatic moment. The central concerns of Media Studies do not translate easily in the region, especially when the analytic tools and the normative preoccupations operate so closely in tandem. However, that is not to say that we jettison our conceptual tools. We might take concepts from these three paradigms for a walk in the region, as well as try to build new concepts from the ground up. We might try to do both together.

\section{What's the Point of a Regional Focus?}

What does a regional focus enable us to think about, what does it offer us conceptually? Ironically, the strong critique of 'area studies' by Said (1981) focused on the framing of the Middle East by the triumvirate of government, media and academe. Much of the problem stemmed from framing the region as an 'exceptional case', with little 'economy' and not much 'politics', so we need to be wary of repeating the same mistakes. What are the similarities and differences within and between different regions? If the social sciences helped universalize the 'province' of Europe, does the remergence of regional foci 'provincialize' the 'West'? Are we going to end up with isolated but deep 'patches' 
of analysis, or can we make a meaningful, coherent quilt out of different regional colors that also includes Europe/the West?

I think there are, at least, three main 'spatial frames' that invite analysis: the national, the regional and the trans-national.

Earlier I was perhaps too dismissive of studies of national systems. While no longer the only frame, that does not mean that this level of analysis has no utility; of course it does, both as the container of political and economic lives, as the loci of decision-making, and the source of certain kinds of identity-formation. The nation is dead, long live the nation! We could have histories of media, analyses of media policy, contemporary political debate, etc., of the nations of the region.

Such a national level of analysis can explore internal divisions and tensions, whether by class, gender, age, etc., and by the range of political and other viewpoints manifest in the national media system. It is the most obvious and most common form of analysis in the field. Why should there not be as rich an analytic literature on, say, Egyptian media and contemporary culture as there is on French?

Regional analysis is perhaps most obviously about comparison. First, we might make intra-regional comparisons. If what I have suggested has any purchase, then comparisons across these peculiar forms of political power, which are not really states in the liberal sense but regimes that manifest various forms of repression, will tell us much about the detailed practices of power and potentially contribute to a better understanding of non-liberal political configurations, an extra-disciplinary effect. Such work would interrogate and extend attempts to develop comparative models of media systems, most usefully that by Hallin and Mancini (1996) which has, so far, only examined European systems. But second, to avoid over-exceptionalism, we might make inter-regional comparisons. How do Middle East states and polities differ from, say, Latin American or East Asian states, and what implications does this have for their development strategies, for their class formations, for their media and communicative systems?

Regional dynamics are also about competition: for readers, listeners and viewers, for discursive influence and ideological dominance. Sometimes, they are also about war. Comparisons of media content for dominant tropes and who those belong to; comparisons of audiences for what they are tuning in to would start to build indices and measures of regional power. Is, for example, the notion of a 'Shi' ite-Sunni' split equally evident in the press across the Arab world and in Iran? What, if any, are the counter-arguments? What are considered to be the regional fissures and blocs, by whom and how are these articulated? Which is winning the influence game, Al-Jazeera or Al-Arabiya? And so on. The space afforded by this journal should trigger analyses at the regional level. 
The transnational level of analysis situates the region within broader frames of reference, 'flows' of peoples and pictures, markets and meaning-claims. How do various countries think about and represent the 'West' but also, increasingly now, the 'East' and what are the implications for diplomacy and international relations? Which non-regional countries are considered significant, with whom are there bilateral arrangements, what cultural product is being absorbed? How important are diasporic populations to the construction of media content, to the cultural economy, to the nature of political debate? Are they happily 'expelled' or are they invited back, and what do they do when they return? Most centrally, of course, is the issue raised by Anderson (2007) as to why the US aim of rolling out capitalism around the globe has succeeded relatively peacefully in most areas, what he calls the 'house of harmony', while it led to the 'house of war' in the Middle East. Even now, five years after the invasion of Iraq, the best independent minds cannot agree as to the cause. Anderson suggests a mix in the USA of 'one-eyed special interests... unhinged ideological zealots' (Anderson 2007: 12-3) coupled with, in the region, on-going concern about Iraq, desperation over Palestinian statehood and the psychological blow of 9-11, meaning that global US hegemony is most obviously undermined through its military adventures in the Middle East.

My intention here has not been to legislate what 'we' should be researching nor how, but to explore the manner in which both broader conceptual frameworks and more nuanced, grounded and subtle forms of media and contemporary cultural analyses can contribute to a better understanding of both the region and of media studies. I think we need better analysis of the political economies of the region, the nature of their politics and more grounded cultural studies and far, far better conversations across these registers. A sensitivity to varied and competing spatial orders and levels of analysis can thicken the conceptual soup and produce innovative thinking.

\section{To Conclude}

The Middle East is a highly complex region, and any attempt to describe its processes of political change and democratization has to be mindful of the real historical and contingent differences and particular political economies that exist. No essentialist or culturalist models will suffice. Further, the region's insertion into the global political economy, indeed the differential roles of particular states within the global order and the varying impacts of markets, migration and media, have to be considered. The pressures toward and dynamics of political change need to be examined both from outside and from inside the region. 
Thus the focus of this journal is both to be welcomed and grasped as a considerable challenge. Neither limiting the focus to Arab nations nor to Islamic issues and concerns, as some organizations and journals do, the broad approach advocated here should foster a new and more varied research agenda. This is especially welcome as the contemporary conflicts in and the politics of the region are bringing new issues to the fore.

The Middle East is the terrain upon which much of the West's current ambitions and fears are invested. It is where the shifting boundary of Europe tends to fray, as the Turkish army makes incursions over the Iraqi border to deal with Kurdish 'insurgents' while at the same time petitioning to join the European Union. It is where external, US-originated rhetoric about 'bringing democracy to the region' triggers new lines of tension that include the concern of Arab states about the rise of Iranian influence and the strengthening of both the discourse and the reality of 'Sunni-Shi' ite' confrontations, while creating a massive Iraqi refugee population dispersed across the region and putting severe demands on many of the neighboring states. There remains the on-going tragedy for all concerned of Israeli expansionism, the absence of a Palestinian state and the new internal and violent divisions in Palestinian politics. It is also the region with probably the world's highest levels of finance capital, amassed through years of primitive accumulation based on oil rent with prices now the highest on record; but also a region with very dynamic relations between diasporas and homes that includes not only hawala but also growing inward and return investment into the booming Arab markets.

Critique of the essentially 'Eurocentric' roots and assumptions of Media Studies is badly needed, but that often leads to simplistic notions of 'indigeneity' untouched by the West and advocacy of rather naïve notions about 'indigenous research approaches'. Azmi Bishara (2004) has brilliantly argued that part of the tension between the Christian West and Islam stems precisely from the fact that Islam grew from within that tradition yet refashioned it, a schismatic process that has left a certain legacy of bitterness. The growth of discourse about 'Abrahamic' roots is perhaps one response to that old schism, an attempt to rebuild understanding across the three religions. Such discourse is not simply a project triggered by multicultural concerns in the West. The letter from President Ahmadi-Nejad to President Bush in May 2006 invoked the common Abrahamic religious roots between the two men and their respective countries (Sreberny 2008). Clearly, the claims are to a shared history and have some ethical purchase.

As always, a focus on the region summons Said's Orientialist concern that, in describing 'others', 'we' are actually talking mainly about ourselves. I am very aware of writing this on a sunny and peaceful day in London while, in the region, violence, repression and poverty are experienced by many. 
Anidjar (2003) argues that to understand Europe fully is to acknowledge its two counter-figures, that of the Jew contructed as the religious 'insider' and the 'Arab' constructed as the political 'outsider'; indeed, the very conceptual terrain of what constitutes the 'religious' and the 'political' derives from these historical processes. Thus the Abrahamic religions are seen as imbricated in a long and conflictual history that partly explains the political cathexis between the West and the region. Levering Lewis (2008), in his new book on the early encounter between Europe and Islam, dares to argue that Europe would have been three centuries ahead if it had not expelled the Moors. The historic pre-eminence of Arab thought, Islamic architecture, Persian poetry, does pose the often inarticulate question: what happened and how have Arab and Middle Eastern intellectuals and artists become so caged?

It is to be hoped that this journal can keep the internal and external dynamics of the region in tension and explore the West's constructions of - and interference in - the region as well as the region's multiple discourses and engagements among itself and with the West. Now that there is an outlet for such focused work, it is to be hoped that new, serious and hard-hitting work will emerge, including reflexive critique by intellectuals in the region. The specific object of study might provide new tools for the expansion of the subject. It is difficult to think of a more pertinent or pressing focus for a journal.

\section{References}

Ahmad, Ajaz (2008). Islam, Islamisms and the West. In Panitch, Leo and Leys, Colin (Eds.) Global Flashpoints: Reactions to Imperialism and Neo-Liberalism, Socialist Register, pp. 1-37. Monmouth: Merlin Press.

Anidjar, Gill (2003). The Jew, the Arab: A History of the Enemy. Stanford: Stanford University Press. Anderson, Perry (2007). Jottings on the Conjuncture. New Left Review, 48, pp. 5-38. Nov.-Dec. 2007.

Beck, Ulrick (2002). The Terrorist Threat. Theory, Culture and Society, 19(4): 39-55.

Bishara, Azmi (2004). Public talk, SOAS, University of London.

Curran, James and Park, Myung-Jing (Eds.) (2000). De-Westernizing Media Studies. London: Routledge.

Dabashi, Hamid (2007). Iran: A People Interrupted. New York: The New Press.

Davies, Mike (2006). Fear and Money in Dubai. New Left Review, 41, pp. 47-70, Sep.-Oct. 2006. Harvey, David (2003). The New Imperialism. Oxford: Oxford University Press.

Huntington, Samuel (1965). Political Development and Political Decay. World Politics, 17(3): 386-430.

Kelley, Ron, Jonathan Friedlander and Anita Colby (1993). Irangeles. Berkley: University of California Press.

Khiabany, Gholam (2007). Iranian Media: The Paradox of Modernity. Social Semiotics, 17(4): 479-501.

Khiabany, Gholam and Sreberny, Annabelle (forthcoming). Blogistan. London: IB Tauris. 
Lerner, David (1958). The Passing of Traditional Society: Modernizing the Middle East. New York: The Free Press.

Levering Lewis, David (2008). God's Crucible: Islam and the Making of Europe, 570-1215. London: W. W. Norton.

Luciani, Giacomo (1994). Oil Rent, the Fiscal Crisis of the State and Democratization. In Salamé, Ghassan (ed), Democracy without Democrats? The Renewal of Politics in the Muslim World, pp. 130-155. London: IB Tauris.

Mahdavy Hossein (1970). Patterns and Problems of Economic Development in Rentier States. In Cook, Michael Allan (ed), Studies in the Economic History of the Middle East: The Case of Iran, pp. 37-61. London: Oxford University Press.

MERIP (1992). The Democracy Agenda in the Arab World. MERIP Report, 174(22.1) JanuaryFebruary 1992.

Mowlana, Hamid and Wilson, Laurie J. (1990). The Passing of Modernity: Communication and the Transformation of Society. London: Longman.

Said, Edward (1981). Covering Islam. New York: Pantheon.

Sharabi, Hisham (1988). Neo-Patriarchy: A Theory of Distorted Change in Arab Society. Oxford: Oxford University Press.

Singerman, Diane and Amar, Paul (Eds.) (2006). Cairo Cosmopolitan. Cairo: American University in Cairo Press.

Sreberny, Annabelle (1997). The Many Cultural Faces of Imperialism. In Golding, Peter and Harris, Phil (Eds.), Beyond Cultural Imperialism: Globalization, Communication, and the New International Order, pp. 51-68. Thousand Oaks, CA: Sage.

Sreberny, Annabelle (1998). Media and Democratization in the Middle East: The Strange Case of Television. In Randall, Vicky (ed). Democratization and the Media, special issue of Democratization, 5(2): 179-199.

Sreberny, Annabelle (2000). Television, Gender and Democratization in the Middle East. In Curran, James and Park, Myung-Jing (Eds.), De-Westernizing Media Studies, pp. 63-78. London: Routledge.

Sreberny, Annabelle (2008). One Letter, Two Presidents and a Global Audience: The Shifting Spatialities of Contemporary Communication. In Hesmondhalgh, David and Toynbee, Jason (Eds.), The Media and Social Theory. London: Routledge.

Sreberny-Mohammadi, Annabelle and Mohammadi, Ali (1994). Small Media, Big Revolution: Communication, Culture and the Iranian Revolution. Minneapolis: University of Minnesota Press.

Strange, Susan (1997). Casino Capitalism. Manchester: Manchester University Press. 